\title{
PENGEMBANGAN BAHAN AJAR VOLUME BANGUN RUANG BERBASIS PENDEKATAN SCIENTIFIC
}

\author{
Amalia Nurjannah \\ Sekolah Tinggi Ilmu Tarbiyah Raudhatul Ulum Sakatiga \\ Email: amalia_nurjannah@ymail.com
}

\begin{abstract}
Abstrak
Tujuan penelitian ini adalah untuk menghasilkan bahan ajar volume bangun ruang berbasis pendekatan scientific yang valid dan praktis dan memiliki efek potensial terhadap hasil belajar. Subjek penelitian adalah siswa kelas VIII SMP Islam Terpadu Raudhatul Ulum Sakatiga yang berjumlah 20 orang. Metode yang digunakan pengembangan atau development research. Pengumpulan data yang dilakukan dalam penelitian ini menggunakan dokuman, walk trough, video, observasi, dan tes. Hasil penelitian ini telah menghasilkan bahan ajar yang valid dan praktis yang sesuai dengan langkahlangkah pendekatan scientific pada materi volume bangun ruang. Valid tampak dari hasil validasi beberapa validator berdasarkan konten, konstruk, dan bahasa dan hasil one-to-one. Praktis tampak dari hasil pengamatan small group dan diperoleh bahan ajar yang mudah digunakan sesuai dengan kebutuhan siswa. Selain valid dan praktis, bahan ajar ini juga mempunyai efek potensial terhadap hasil belajar siswa SMP Islam Terpadu Raudhatul Ulum Sakatiga kelas VIII.
\end{abstract}

Kata Kunci: Pengembangan, Volume Bangun Ruang, Pendekatan Scientific

\section{Pendahuluan}

Memasuki tahun ajaran 2013/2014 kurikulum 2013 mulai diterapkan di sekolah-sekolah. Penerapan kurikulum 2013 ini dikarenakan adanya berbagai tantangan yang dihadapi selama ini, salah satunya adalah masalah pendalaman dan perluasan materi (Kemdikbud (a), 2013:67). Hal ini dapat dilihat dari kualitas pendidikan matematika di sekolah dasar dan menengah di Indonesia yang masih jauh ketinggalan dibandingkan dengan negara lain di dunia. Dari hasil PISA menunjukkan bahwa prestasi murid Indonesia masih berada pada peringkat bawah, dari 65 negara yang mengikuti PISA 2009, Indonesia mendapat ranking ke 64 untuk mata pelajaran Matematika (OECD, 2014). Fauzan (2002) menambahkan bahwa salah satu permasalahan terbesar yang berkait dengan matematika modern ialah penyajian matematika sebagai produk jadi, siap pakai, abstrak dan diajarkan secara mekanistik: guru mendiktekan rumus dan prosedur ke siswa. Aktivitas-aktivitas pada pembelajaran konvensional mengakibatkan terjadinya proses penghafalan konsep atau prosedur, pemahaman konsep mereka menjadi rendah. Akibat dari pembelajaran yang konvensional tersebut adalah bahwa siswa dalam belajar matematika lebih diarahkan pada proses menghafal daripada memahami konsep (Somakim, 2009). 


\section{Pengembangan Bahan Ajar Volume Bangun Ruang Berbasis Pendekatan Scientific Amalia Nurjannah}

Untuk mengatasi permasalahan di atas perlu dilakukan modifikasi terhadap proses pembelajaran. Menurut Pitadjeng (2005) agar murid dapat belajar matematika dalam suasana yang menyenangkan guru harus mengupayakan adanya situasi dan kondisi yang menyenangkan, strategi yang menyenangkan, maupun materi matematika yang menyenangkan.

Sejalan dengan hal tersebut, guru matematika dituntut secara profesional untuk menyiapkan dan melaksanakan proses pembelajaran matematika yang sesuai dengan tujuan yang ingin dicapai pada kurikulum 2013. Oleh karena itu, guru harus mempunyai kemampuan dalam mengembangkan dan mendesain sendiri bahan pembelajaran yang dapat membuat siswa aktif dan kritis. Pembelajaran matematika yang aktif, inovatif, dan menyenangkan bagi siswa merupakan hal yang perlu dilaksanakan dalam proses pembelajaran matematika. Banyak cara yang bisa dilakukan guru untuk menciptakan pembelajaran di atas, misalnya dengan suatu pendekatan yang sesuai dengan kurikulum 2013. Pendekatan yang digunakan pada kurikulum 2013 adalah pendekatan scientific.

Pendekatan scientific/ilmiah (Kemdikbud (b), 2013) merupakan suatu cara atau mekanisme untuk mendapatkan pengetahuan dengan prosedur yang didasarkan pada suatu metode ilmiah. Pendekatan scientific juga diartikan sebagai mekanisme untuk memperoleh pengetahuan yang didasarkan pada struktur logis. Pendekatan ilmiah diyakini sebagai titian emas perkembangan dan pengembangan sikap, keterampilan, dan pengetahuan peserta didik (Kemdikbud (b), 2013). Proses pembelajaran dalam pendekatan scientific terdiri atas lima pengalaman belajar yaitu: mengamati, menanya, menalar, mencoba dan mengkomunikasikan (Kemdikbud (c), 2013).

Materi yang dijadikan kajian dalam pengembangan ini yaitu materi volume bangun ruang sisi datar. Materi bangun ruang tercakup dalam ruang lingkup aspek geometri yang dipelajari pada kelas VIII SMP semester genap. Berdasarkan kurikulum 2013 kompetensi dasarnya adalah menentukan luas permukaan dan volume kubus, balok, prisma, dan limas.

Materi bangun ruang merupakan bagian dari geometri yang menekankan pada kemampuan siswa untuk mengidentifikasi sifat, unsur, dan menentukan volume dalam pemecahan masalah (Rostika, 2008). Isa (2011) menambahkan bangun ruang merupakan sub konsep dari geometri yang berhubungan dengan bentuk dari benda yang mempunyai panjang, lebar, dan tinggi sebagai unsur-unsurnya. Mengingat tuntutan terhadap penguasaan materi bangun ruang, agar tujuan pembelajaran matematika dapat tercapai optimal, maka guru hendaknya memberikan kesempatan kepada siswa untuk mengembangkan segala potensinya dan membangun sendiri pengetahuannya.

Namun kenyataan di lapangan, hasil belajar siswa dalam materi geometri khususnya menentukan volume bangun ruang masih lemah karena siswa tidak bisa mengaitkan persoalan bangun ruang ke dalam persoalan sehari-hari. Hal ini sejalan dengan hasil penelitian Markaban bahwa hasil training Need Assessment yang dilaksanakan Pusat Pengembangan dan Pemberdayaan Pendidik dan Tenaga 
Volume 2 Nomor 1 Edisi Juni 2017

P-ISSN : 2541-3686

Kependidikan (PPPPTK) Matematika tahun 2007 dengan sampel sebanyak 268 pendidik sekolah Menengah Pertama (SMP) dari 15 propinsi menunjukkan bahwa sebanyak $43,7 \%$ guru masih memerlukan pendalaman materi luas permukaan dan volume balok, kubus, prisma, serta limas, sebanyak 48,1\% guru masih memerlukan pendalaman materi sifat-sifat kubus, balok, prisma, dan limas serta bagianbagiannya, sebanyak $48,1 \%$ guru masih memerlukan pendalaman materi pembuatan jaring-jaring kubus, balok, prisma, dan limas, dan sebanyak 45,9\% guru masih memerlukan pendalaman materi unsur-unsur tabung, kerucut, dan bola (Suwaji, 2008:1).

Bahan ajar merupakan sebuah perangkat yang penting untuk menjadi acuan terlaksananya sebuah pembelajaran. Bahan ajar dapat memberikan arahan tentang apa yang harus dipahami siswa sebab bahan ajar ini adalah salah satu perwujudan dari tujuan dan isi dari silabus. Bahan ajar adalah segala bentuk bahan berupa seperangkat materi yang disusun secara sistematis yang digunakan untuk membantu guru/instruktur dalam melaksanakan kegiatan pembelajaran dan memungkinkan siswa untuk belajar (Depdiknas, 2010:27).

Bahan ajar yang dikembangkan terlebih dahulu divalidasi oleh pakar dan teman sejawat. Cara ini dikenal dengan teknik triangulasi. Triangulasi adalah suatu proses validasi silang di antara berbagai sumber, teknik pengumpulan data, berbagai waktu, dan atau skema teori yang digunakan dalam mengartikan data (Anggoro, 2008:6.20). Menurut Nieveen (Akker, 1997) menyatakan suatu perangkat pembelajaran dikatakan baik jika memenuhi aspek kualitas seperti (1) validitas (validity), (2) kepraktisan (practically), (3) keefektifan (effectiveness).

Berdasarkan uraian maka peneliti perlu untuk mengembangkan bahan ajar yang sesuai dengan kurikulum 2013 khususnya menggunakan pendekatan scientific. Maka peneliti berfokus mengembangkan bahan ajar volume bangun ruang berbasis pendekatan scientific di kelas VIII. Permasalahan dalam penelitian ini adalah Bagaimana mengembangkan bahan ajar volume bangun ruang yang valid dan praktis yang berdasarkan pendekatan scientific dan apakah bahan ajar volume bangun ruang berbasis pendekatan scientific yang dikembangkan memiliki efek potensial terhadap hasil belajar matematika siswa.

Tujuan yang akan dicapai dalam penelitian ini adalah menghasilkan bahan ajar volume bangun ruang yang valid dan praktis, yang dikembangkan berdasarkan pendekatan scientific dan mengetahui efek potensial yang muncul dari pengembangan bahan ajar volume bangun ruang terhadap hasil belajar siswa.

\section{Metode Penelitian}

Penelitian ini menggunakan metode penelitian design research tipe development study (Nieveen, McKenney, dan Akker, 2006). Subjek penelitian ini adalah siswa kelas VIII SMP IT Raudhatul Ulum Sakatiga. 


\section{Pengembangan Bahan Ajar Volume Bangun Ruang Berbasis Pendekatan Scientific Amalia Nurjannah}

Bahan ajar yang dikembangkan adalah bahan ajar volume bangun ruang berbasis pendekatan scientific di kelas VIII. Dalam penelitian ini terdiri dari dua tahap, yaitu: preliminary (tahap persiapan dan pendesainan bahan ajar) dan formative study (tahap evaluasi dan tahap revisi) (Zulkardi, 2002). Dalam tahap preliminary dilakukan analisis yaitu analisis siswa, analisis kurikulum dan menyiapkan materi volume bangun ruang yang akan dikembangkan dengan menggunakan pendekatan scientific. Dan desain yaitu peneliti mendesain bahan ajar menggunakan pendekatan scientific dengan materi volume bangun ruang yang berfokus pada karakteristik yaitu isi, konstruk, dan bahasa.

Tahap formative evaluation terdiri dari self evaluation, expert review, one-to-one, small group, dan field test. Pada tahap self evaluation dilakukan penilaian oleh diri sendiri terhadap hasil desain bahan ajar yang telah dibuat oleh peneliti, sehingga menghasilkan prototipe I. Pada tahap expert review dan one-to-one hasil dari prototipe I yang telah dikembangkan diberikan ke pakar/ahli untuk menelaah konten, konstruk, dan bahasa dan 3 orang siswa (one-to-one) secara pararel. Saran-saran dan hasil validasi pakar serta hasil uji coba one-to-one dijadikan dasar untuk merevisi prototype I ini dan hasil revisinya dinamakan prototype II. Kemudian small group yaitu evaluasi yang digunakan evaluator dalam mengujicobakan bahan ajar yang telah direvisi pada suatu kelompok siswa dan mencatat komentar-komentarnya. Saransaran dan komentar serta hasil uji coba pada prototype II ini dijadikan dasar untuk merevisi desain prototype II. Hasil revisi dinamakan prototype III. Dan tahap terakhir field test yaitu pada tahap ini prototype III akan digunakan sebagai bahan ajar dan diujicobakan ke subjek penelitian. Uji coba ini bertujuan untuk melihat efek potensial dari prototype terhadap hasil belajar.

Teknik pengumpulan data yang digunakan dalam penelitian ini adalah dokumen, walk trough, video, observasi dan tes. Dokumen yang dimaksud adalah hasil pekerjaan siswa pada prototype yang digunakan untuk melihat efek potensial dari prototype. Walk trough atau catatan validator dilakukan dengan pakar/pembimbing, dan digunakan untuk melihat validitas bahan ajar, yang meliputi validitas isi, validitas konstruk, dan validitas bahasa. Data dokumen berupa saran dan komentar dari pakar dianalisis serta digunakan untuk merevisi prototipe hingga valid. Rekaman dilakukan pada saat one-to-one, small group, dan field test. Hasil dari video digunakan sebagai bahan analisis dan pembanding terhadap data dokumen yang didapatkan. Pada penelitian ini, Observasi dilakukan terhadap siswa field test untuk memperoleh data mengenai sikap siswa dalam mempelajari bahan ajar yang dikembangkan berdasarkan pendekatan scientific. Tes digunakan untuk mengukur kompetensi pengetahuan dan keterampilan siswa setelah mendapatkan pembelajaran dengan pendekatan scientific.

Hasil walk trough dengan pakar, one-to-one, dan small group dianalisis secara deskriptif sebagai masukan yang digunakan untuk merevisi pada setiap langkah pengembangan prototype. Sedangkan untuk melihat sikap siswa selama proses pembelajaran maka dilakukan pengamatan, aspek yang diamati sesuai dengan 
Volume 2 Nomor 1 Edisi Juni 2017

P-ISSN : 2541-3686

lembar observasi yang dibuat. Hasil observasi dikonversikan ke dalam data kualitatif untuk menentukan kategori sikap siswa selama proses pembelajaran.

Dokumen berupa hasil tes siswa yang diberikan pada akhir proses pembelajaran dianalisis secara deskriptif kualitatif. Skor yang diperoleh siswa dari hasil tes dikonversikan dari rentang 0 sampai 100. Hasil dari nilai siswa dikonversikan ke dalam bentuk data kualitatif untuk mengetahui hasil belajar aspek pengetahuan dan keterampilan siswa.

\section{Hasil Dan Pembahasan}

\section{Hasil Pengembangan Bahan Ajar}

Pada penelitian pengembangan ini menghasilkan bahan ajar berupa Lembar Kerja Siswa (LKS) yang berbasis pendekatan Scientific yang valid, praktis, dan mempunyai efek potensial terhadap hasil belajar pada siswa SMP Islam Terpadu Raudhatul Ulum Sakatiga. Proses pengembangan bahan ajar melalui dua tahapan, preliminary dan formative study. Pada tahap preliminary Study, peneliti melakukan analisis dan desain, pada analisis kegiatan terfokus pada analisis siswa dan analisis kurikulum. Pada tahap pendesainan, peneliti mendesain bahan ajar berupa lembar kerja siswa berbasis pendekatan scientific, perangkat pembelajaran berupa RPP dan instrumen penilaian.

Pada tahap Formative Study ada tiga tahapan yaitu Self Evaluation, expert review dan one-to-one, dan field test. Pada tahap self evaluation, peneliti membuat draf LKS volume bangun ruang sisi datar berbasis pendekatan scientific, setelah dibaca dan di evaluasi maka menghasilkan prototype pertama yang difokuskan pada konten, konstruk, dan bahasa.

Hasil dari prototype 1 yang telah dikembangkan atas dasar self evaluation divalidasi oleh beberapa pakar dan teman sejawat yaitu guru matematika yang sudah berpengalaman dalam pendidikan matematika.Tahap ini bertujuan untuk memperoleh bahan ajar yang valid. Prototype 1 yang diberikan kemudian divalidasi dari segi konten, konstruk, dan bahasa. Adapun komentar dan saran dari pakar dan teman sejawat sebagai validator peneliti rangkum pada Tabel 1.

Tabel 1. Saran dari pakar dan teman sejawat serta keputusan revisi

\section{Prototype 1}

Keputusan Revisi

\section{(Komentar/Saran validator)}

Pola pikir terbalik, harus berpola pikir deduktif mulai dari balok ke kubus

$>$ Penggunaan istilah volum, isi, kapasitas, serta debit harus tepat

$>$ Merubah satuan volume dari kubik ke liter dan sebaliknya dimantapkan
Sudah diperbaiki sesuai saran

Sudah diperbaiki sesuai saran 
LKS kurang langkah scientific secara eksplisit

$>$ Sudah diperbaiki, setiap

LKS sudah dicantumkan

langkah scientific $5 \mathrm{M}$

$>$ Sebaiknya dicek penulisan kata volume di kbbi online yang benar volum atau volume

Ada beberapa gambar yang harus diperjelas

Pada setiap gambar harus diberi keterangan

Beberapa kata diperbaiki pada LKS
Sudah diperbaiki

Gambar sudah diperjelas

Setiap gambar sudah diberi keterangan

$>$ Sudah diperbaiki sesuai saran

Seiring dengan tahap expert review dilakukan tahap one-to-one. Pada tahap ini prototype 1 diujicobakan kepada tiga siswa kelas VIII SMP IT Raudhatul Ulum Sakatiga yang bukan subjek penelitian. Ujicoba dilakukan untuk melihat kesulitankesulitan yang mungkin terjadi selama proses penggunaan LKS dalam pembelajaran. Setelah belajar dengan menggunakan LKS berbasis pendekatan scientific, ketiga siswa tersebut diminta memberikan komentarnya. Adapun komentar dan saran dari siswa one-to-one peneliti rangkum pada Tabel 2.

Tabel 2. Saran dari one-to-one serta keputusan revisi

\section{Prototype 1}

Keputusan Revisi

\section{(Komentar/Saran validator)}

$>$ LKS volume bangun ruang ini bagus, Cuma ada beberapa soal yang sulit dimengerti seperti:

1. LKS Balok

Masalah 1 pada no. 2 "ke dalam tempat minyak itu?" (sampai penuh / tidak?)

2. LKS Kubus

\section{Sudah diperbaiki}

Masalah 3 kurang dimengerti soal itu karena maksud menara disana yang gimana, sebaiknya menggunakan gambar agar mudah dimengerti

3. LKS Prisma

Masalah 3 gambarnya tidak sesuai soal. Kurang Sudah diperbaiki, gambar sudah ditambahkan. jelas pada gambar, maksud dari gambar soal

4. LKS Limas

Bingung menentukan Volume limas didapat dari 
Gambar tidak diganti

karena permasalahan yang diberikan menuntut siswa untuk bisa menalar. Sudah diperbaiki

Pada tahapan Small Group, prototype kedua yang dihasilkan dari dua tahap sebelumnya diujicobakan kepada 5 orang siswa kelas VIII SMP IT Raudhatul Ulum Sakatiga bukan subjek penelitian dalam satu kelompok dengan kemampuan heterogen. Siswa diminta untuk mengerjakan LKS yang telah dibuat, dari hasil pekerjaan mereka terlihat bahwa mereka dapat menggunakan LKS tersebut. Keterpakaian LKS pada tahap small group ini menunjukkan bahwa LKS ini dapat dikatakan praktis. Setelah belajar dengan menggunakan LKS ini, siswa diminta memberikan komentar mereka. Peneliti berinteraksi untuk melihat kesulitankesulitan yang mungkin terjadi selama proses pengerjaan LKS sehingga dapat memberikan indikasi apakah perlu diperbaiki atau tidak. Hasil perbaikan prototype kedua ini diperoleh prototype ketiga.

Pada tahap field test dilakukan uji coba setelah melalui beberapa tahapan dan menghasilkan bahan ajar yang valid dan praktis. Uji coba ini dilakukan pada siswa kelas VIII.B 2 SMP IT Raudhatul Ulum Sakatiga dengan jumlah 20 orang, yang dibagi menjadi 5 kelompok yang memiliki kemampuan berbeda-beda. Proses pengambilan data pada penelitian ini dilakukan sebanyak 5 kali pertemuan, yaitu pertemuan pertama dan kedua pada tanggal 20 September 2014, pertemuan ketiga tanggal 22 September 2014, pertemuan keempat tanggal 25 September 2014, dan pertemuan kelima tanggal 29 September 2014.

Pengumpulan data sikap siswa dilakukan dengan menggunakan lembar observasi selama proses pembelajaran dengan menggunakan pendekatan scientific. Dalam pembelajaran masing-masing kelompok diberikan lembar kerja siswa dengan pokok bahasan volume bangun ruang sisi datar yang harus mereka kerjakan dan diskusikan bersama anggota kelompoknya. LKS ini dirancang dengan menggunakan lima langkah pendekatan scientific yaitu mengamati, menanya, menalar, mencoba, dan mengkomunikasikan. Pada saat pelaksanaan pembelajaran tersebut, peneliti dibantu oleh 2 orang observer yaitu Rantan Dwijayanti, S.Pd dan Ruaida Rati, S.Pd yang bertugas mengamati aktivitas/sikap siswa selama proses pembelajaran.

Hasil observasi sikap siswa selama proses pembelajaran disajikan pada Tabel 3.

Tabel 3. Hasil Belajar Aspek Sikap Siswa

Nilai Akhir Frekuensi $\quad$ Persentase Kategori Sikap




\begin{tabular}{cccc}
\hline $80-100$ & 17 & $85 \%$ & Sangat Baik \\
$66-79$ & 3 & $15 \%$ & Baik \\
$56-65$ & 0 & $0 \%$ & Cukup \\
$40-55$ & 0 & $0 \%$ & Kurang \\
$0-39$ & 0 & 0 & Sangat Kurang \\
\hline Jumlah & 20 & $100 \%$ & \\
\hline
\end{tabular}

Adapun contoh hasil jawaban siswa pada bahan ajar pertemuan 1 aktivitas mengamati dapat dilihat pada Gambar 1

Gambar 1

Jawaban siswa pada aktivitas mengamati



Semua kelompok menjawab sesuai dengan harapan peneliti pada kolom jawaban. Artinya semua kelompok memahami maksud petunjuk dalam melakukan aktivitas. Pada aktivitas mengamati, siswa dituntut untuk menyusun kubus-kubus satuan membentuk balok dan mengamatinya sesuai perintah pada lembar kerja siswa, kemudian siswa menentukan ukuran-ukuran dari alat peraga yang telah mereka susun dan menentukan volume dari masing-masing alat peraga, diperoleh dari hasil pengamatan bahwa semua siswa melakukan aktivitas. Berdasarkan pengamatan peneliti, semua siswa melakukan aktivitas sesuai petunjuk yang ada pada LKS.

Setelah aktivitas mengamati, selanjutnya siswa melakukan aktivitas menanya. Contoh hasil jawaban siswa pada aktivitas menanya dapat dilihat pada Gambar 2. 
RAUDHAH Proud To Be Professionals gurnal Tarbiyakndlamiyak

Volume 2 Nomor 1 Edisi Juni 2017

P-ISSN : 2541-3686

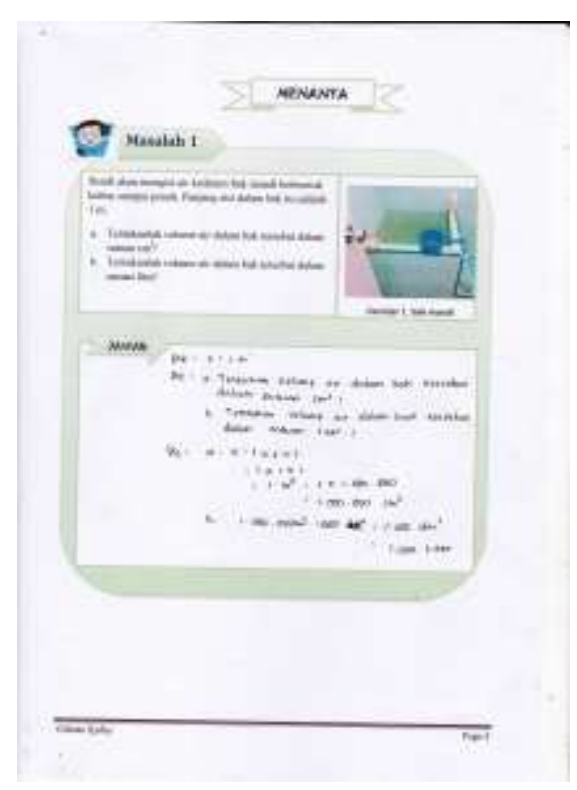

Gambar 2.

Jawaban siswa pada aktivitas menanya

Semua kelompok menjawab sesuai dengan harapan peneliti, semua kelompok menjawab dengan baik dan benar. Dengan demikian artinya siswa mampu menyelesaikan soal yang berkaitan dengan kehidupan sehari-hari.

Selanjutnya pada langkah pendekatan scientific berikutnya, yaitu mencoba. Semua siswa dapat menyelesaikan soal dengan baik dan benar. Disini siswa diberi soal dengan penyelesaian yang bermacam-macam dan dengan cara menyelesaikan yang berbeda pula agar mereka mampu berpendapat dan mencoba mencari kemungkinan jawaban yang tepat dari permasalahan yang diberikan. Contoh hasil jawaban salah satu kelompok dapat dilihat pada Gambar 3.

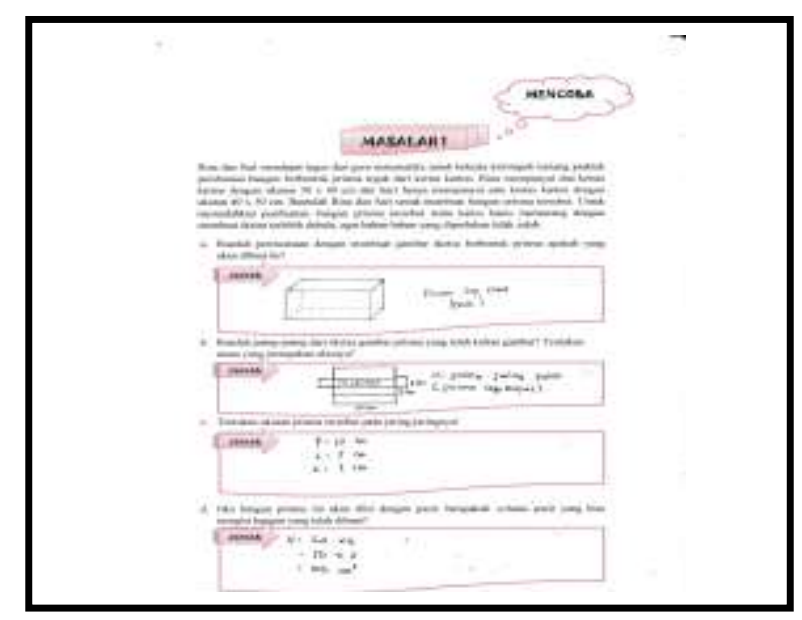

Gambar 3.

Jawaban siswa pada aktivitas mencoba 


\section{Pengembangan Bahan Ajar Volume Bangun Ruang Berbasis Pendekatan Scientific}

Amalia Nurjannah

Dari lembar jawaban siswa diatas, peneliti mengamati bahwa siswa mampu menyelesaikan permasalahan dengan baik, mampu menentukan ukuran dari bangun yang dibuat tanpa melebihi kertas karton yang tersedia dan setiap kelompok mempunyai jawaban yang berbeda tetapi sesuai dengan perintah pada permasalahan yang diberikan.

Langkah berikutnya adalah menalar. Semua kelompok menjawab sesuai dengan harapan peneliti. Meskipun ada beberapa kelompok yang belum sempurna dalam menuliskan informasi dalam soal. Peneliti mengamati terdapat kelompok yang melakukan perhitungan yang keliru. Adapun lembar jawaban kelompok tersebut dapat dilihat pada Gambar 4.

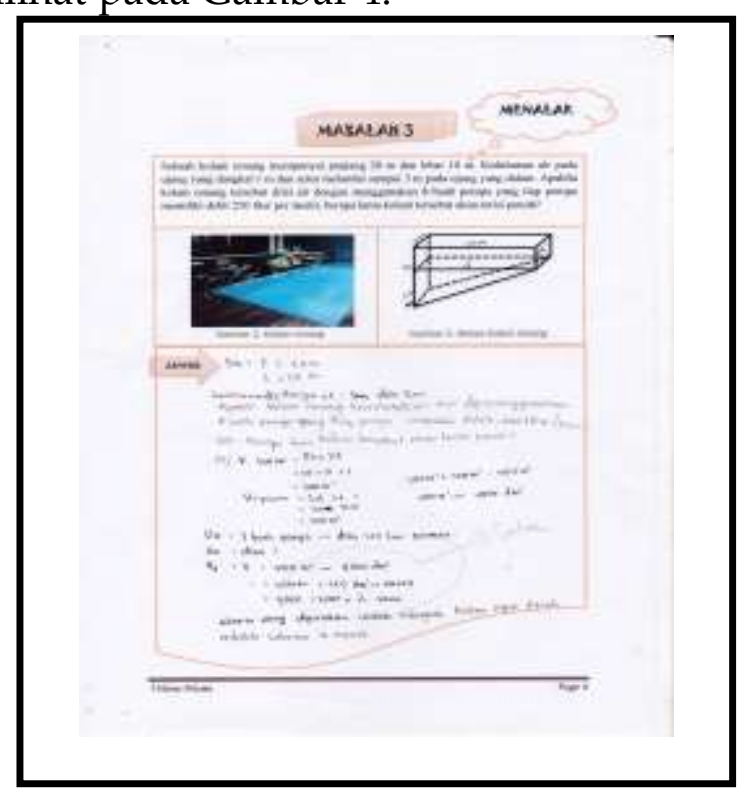

Gambar 4.

Jawaban siswa pada aktivitas menalar

Dari lembar jawaban siswa di atas, peneliti mengamati terdapat kekeliruan perhitungan, hal ini disebabkan siswa tidak teliti dalam menyelesaikan soal, terlihat pada gambar siswa salah dalam mengubah satuan dari $\mathrm{m}^{3} \mathrm{ke} \mathrm{dm}^{3}$ sehingga mempengaruhi perhitungan akhirnya.

Pada pertemuan terakhir, dilakukan tes untuk mengukur kemampuan pengetahuan dan keterampilan siswa. Soal tes diberikan kepada 18 orang siswa dan dikerjakan secara individu. Pada tahap ini peneliti mengoreksi dan menganalisis data penilaian tertulis siswa pada materi volume bangun ruang sisi datar. Adapun tabel distribusi frekuensi hasil belajar aspek pengetahuan dan keterampilan siswa adalah sebagai berikut.

Tabel 4. Hasil Belajar Aspek Pengetahuan Siswa

\begin{tabular}{cccc}
\hline Nilai akhir & Frekuensi & Persentase & Kategori Hasil Belajar \\
\hline $80-100$ & 10 & $55 \%$ & Sangat Baik \\
$66-79$ & 7 & $39 \%$ & Baik \\
$56-65$ & 0 & $0 \%$ & Cukup \\
\hline
\end{tabular}




\begin{tabular}{cccc}
\hline $40-55$ & 1 & $6 \%$ & Kurang \\
$0-39$ & 0 & $0 \%$ & Sangat Kurang \\
\hline Jumlah & 18 & $100 \%$ & \\
\hline
\end{tabular}

Tabel 5. Hasil Belajar Aspek Keterampilan Siswa

\begin{tabular}{cccc}
\hline Nilai akhir & Frekuensi & Persentase & Kategori Hasil Belajar \\
\hline $80-100$ & 7 & $39 \%$ & Sangat Baik \\
$66-79$ & 9 & $50 \%$ & Baik \\
$56-65$ & 2 & $11 \%$ & Cukup \\
$40-55$ & 0 & $0 \%$ & Kurang \\
$0-39$ & 0 & $0 \%$ & Sangat Kurang \\
\hline Jumlah & 18 & $100 \%$ & \\
\hline
\end{tabular}

\section{Pembahasan}

\section{Bahan Ajar yang Valid dan Praktis}

Proses pengembangan bahan ajar yang telah dilalui terdiri dari tiga tahap untuk tiga prototype seperti yang telah dikemukakan terdahulu. Pada tahap prototyping dan proses revisi berdasarkan saran validator dan komentar siswa diperoleh kesimpulan bahwa bahan ajar yang dikembangkan dapat dikategorikan valid dan praktis. Valid tergambar dari hasil penilaian validator menyatakan baik berdasarkan konten (sesuai dengan kompetensi inti dan kompetensi dasar), konstruk (sesuai dengan langkah-langkah pendekatan scientific), dan bahasa (sesuai dengan EYD, kejelasan petunjuk dan arahan, kalimat mudah dimengerti, rumusan kalimat tidak menimbulkan penafsiran ganda). Dari segi kepraktisan, berdasarkan hasil ujicoba small group dapat disimpulkan bahwa bahan ajar yang dihasilkan memenuhi definisi praktis karena siswa mampu mengisi LKS yang diberikan. Sehingga siswa dapat menggunakan LKS tersebut.

\section{Efek Potensial Bahan Ajar terhadap Hasil Belajar Siswa}

Prototype bahan ajar yang sudah dikategorikan valid dan praktis kemudian diujicobakan pada subjek penelitian, dalam hal ini siswa kelas VIII B 2 SMP IT Raudhatul Ulum Sakatiga yang diberi pembelajaran dengan menggunakan pendekatan scientific. Data berdasarkan hasil analisis LKS dan analisis data tes tergambar pada jawaban siswa yang dapat mengisi pertanyaan yang diberikan meskipun jawaban yang diberikan terdapat belum sempurna tetapi sudah mengarah dengan harapan peneliti. Berdasarkan tabel 6 didapat dari hasil belajar aspek pengetahuan siswa dengan kategori sangat baik 55\%, kategori baik 39\%, kategori kurang $6 \%$. Secara rata-rata hasil tes aspek pengetahuan siswa adalah 82 yang termasuk kategori baik. Pada hasil tes akhir terdapat satu siswa yang memiliki nilai 


\section{Pengembangan Bahan Ajar Volume Bangun Ruang Berbasis Pendekatan Scientific Amalia Nurjannah}

hasil evaluasi yang rendah. Gambar 5 adalah jawaban siswa yang hasil belajarnya kurang.

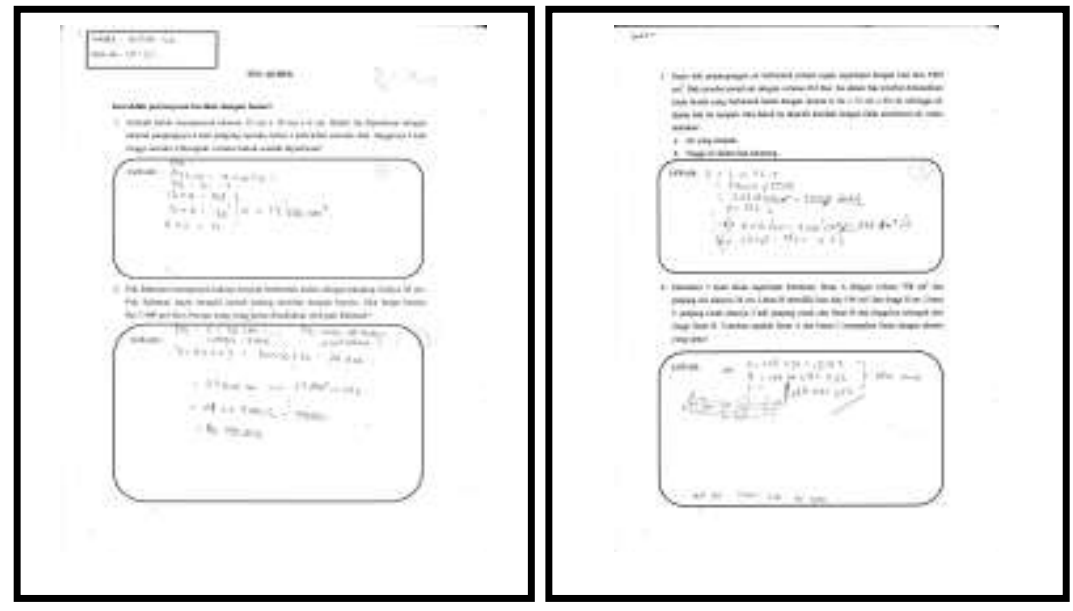

Gambar 5.

Hasil pekerjaan siswa yang nilainya kurang

Jika dilihat dari jawaban siswa pada gambar diatas, pada soal pertama siswa ini menjawab soalnya dengan benar walaupun dalam pengerjaannya tidak terlalu lengkap dan pada soal kedua, siswa ini menjawab soalnya dengan benar dan lengkap. Tetapi pada soal ketiga dan keempat siswa ini menjawab soalnya salah. Menurut hasil wawancara kepada siswa yang bersangkutan, hal ini terjadi karena siswa tersebut tidak hadir pada proses pembelajaran LKS dikarenakan sakit sehingga tidak bisa mengerjakan soal tersebut.

Berdasarkan tabel 5 Hasil belajar aspek keterampilan siswa rata-rata hasil belajarnya adalah 76 yang termasuk kategori baik. Hasil observasi menunjukkan sikap siswa rata-rata hasil dengan kategori sangat baik. Serta dari hasil rekaman video terlihat siswa sangat antusias, bersemangat dalam proses pembelajaran dan terlibat aktif baik diskusi dalam kelompoknya maupun dalam menanggapi presentasi kelompok lain.

Dengan demikian dapat disimpulkan bahwa LKS yang dikembangkan peneliti memiliki efek potensial terhadap hasil belajar siswa atau dengan kata lain, efektif untuk digunakan dalam pembelajaran matematika.

\section{Simpulan}

Valid tergambar dari hasil penilaian validator, dimana LKS yang dikembangkan sudah melalui proses validasi oleh pakar berdasarkan konten (materi sesuai dengan kompetensi inti dan kompetensi dasar), konstruk (sesuai langkahlangkah pendekatan scientific), dan bahasa (sesuai dengan EYD, kejelasan petunjuk dan arahan, kalimat mudah dimengerti, dan rumusan kalimat tidak menimbulkan penafsiran ganda). Praktis tergambar dari hasil ujicoba small group, hasil ini terlihat dalam hal siswa dapat menggunakan dan menyelesaikan Lembar Kerja Siswa (LKS) 
P-ISSN : 2541-3686

berbasis pendekatan scientific pokok bahasan volume bangun ruang sisi datar dengan baik.

Prototype bahan ajar yang dikembangkan memiliki efek potensial terhadap hasil belajar siswa. Hal ini terlihat dari hasil tes aspek pengetahuan siswa dengan rata-rata kemampuan siswa 82 yang termasuk kategori sangat baik. Berdasarkan aspek keterampilan siswa rata-rata hasil belajarnya adalah 76 yang termasuk kategori baik. Dari hasil observasi sikap siswa rata-rata dengan kategori sangat baik. Dari hasil rekaman video juga terlihat aktivitas siswa sangat antusias, bersemangat dan aktif selama proses pembelajaran.

\section{DAFTAR PUSTAKA}

Akker, J.v.d (1999). Principles and Methods of Development Research. Dalam j.v.d Akker, R. Branch, K. Gustafson, N. Nieveen, dan T. Plomp (Ed), Design Approaches and Tools in Education and Training. http://www.heybradfords.com/FormativeResearchInstructionalUnit/Van\%20d er\%20Akker\%20Ch1.pdf. Diakses pada tanggal 6 Maret 2014

Anggoro, M. T. (2008). Metode Penelitian. Jakarta: Universitas Terbuka

Arikunto, S. (2010). Dasar-dasar Evaluasi Pendidikan. Jakarta: Bumi Aksara

Depdiknas. (2010). Juknis Pengembangan Bahan Ajar. Jakarta: Depdiknas

Fauzan, A. (2002). Applying realistic mathematics education in teachin geometry in Indonesian primary schools. Doctoral dissertation. Enschede: Universityof Twente. Tersedia: http://doc.utwente.nl/58707/1/thesis_Fauzan.pdf. Diakses pada tanggal 8 desember 2013

Isa, M. (2011). Hasil Belajar Siswa pada Materi Bangun Ruang Melalui Pendekatan Realistik (Suatu Penelitian pada Anak Kelas VIII SMP Negeri 1 Kuta Malaka Aceh Besar). Jurnal Pendidikan Serambi Ilmu,Vol 10 (1), September 2011. Tersedia: http://lppm.serambimekkah.ac.id/jurnal/jurnalseptember2011.pdf . Diakses pada tanggal 8 desember 2013

Kemdikbud. (2013a). Materi Pelatihan Guru Implementasi Kurikulum 2013. Jakarta: Kemdikbud -. (2013b). Konsep Pendekatan Scientific. Jakarta: Kemdikbud

. (2013c). Lampiran IV Peraturan Menteri Pendidikan dan Kebudayaan Republik Indonesia Nomor 81A Tahun 2013 Tentang Implementasi Kurikulum Pedoman Umum Pembelajaran. Jakarta: Kemdikbud

Nieveen, N., McKenney, S., dan Akker, J.v.d. (2006). Educational Design Research. The Value or Variety. Dalam J.v.d Akker, Gravemeijer, S. McKenney, N. 


\section{Pengembangan Bahan Ajar Volume Bangun Ruang Berbasis Pendekatan Scientific} Amalia Nurjannah
Nieveen
$(\mathrm{Ed})$,
Educational
Design
Research.

http://www.fi.uu.nl/publicaties/literatur/EducationalDesignResearch.pdf.

Diakses pada tanggal 20 Desember 2014

OECD. (2014). PISA 2012 Result in Focus: What 15-Year-Olds Know and What They Can Do With What They Know. www.oecd.org. Diakses pada tanggal 4 Maret 2014

Pitadjeng. (2005). Pembelajaran Matematika yang Menyenangkan. Semarang:Depdiknas Dirjen Dikti

Rostika, D. (2008). Pembelajaran Volume Bangun Ruang Melalui Pendekatan Kontruktivisme untuk Siswa Sekolah Dasar. Jurnal Pendidikan Dasar, 9, April 2008.

Tersedia:

http://file.upi.edu/Direktori/JURNAL/PENDIDIKAN_DASAR/Nomor_9April_2008/Pembelajaran_Volume_Bangun_Ruang_Melalui_Pendekatan_Kon struktivisme_untuk_Siswa_Sekolah_Dasar.pdf . Diakses pada tanggal 08 Desember 2013

Somakim. (2009). Peran Konteks Dalam Meningkatkan Kemampuan Berpikir Kritis Matematik Siswa (Tinjauan Pengembangan Konteks Kesebangunan Berbasis Matematika Realistik). Prosiding Seminar Nasional Pembelajaran Matematika Sekolah.

Tersedia: eprints.unsri.ac.id/.../Prosiding_Semnas_Pembejaran_Mat_6_Des_09.pdf. Diakses pada tanggal 15 Desember 2014

Sopiah, Dwi Istiyani, Nur Khasanah, Perempuan dan Pendidikan Tinggi, Pekalongan, STAIN Press, 2014.

Suwaji, U. T. (2008). Permasalahan Pembelajaran Geometri Ruang SMP dan Alternatif Pemecahan. Yogyakarta: PPPTK Matematika. Tersedia: http://p4tkmatematika.org/fasilitasi/18-Permasalahan-pembelajaramgeometri-ruang-smp.pdf. Diakses pada tanggal 6 Maret 2014

Tessmer, M. (1993). Planning and Conducting Formative Evaluation.Philadelphia: Kogan Page

Zulkardi. (2002). Developing A Learning Environment on RME for Indonesian Student Teachers. Doctoral Dissertation. Enschede: University of twente. Tersedia:doc.utwente.nl/58718/1/thesis_Zulkardi.pdf. Diakses pada tanggal03Maret 2014 